\title{
A hierarquia dos tratados internacionais sobre direitos humanos no Brasil ${ }^{1}$
}

Wagner Junqueira Prado²

\section{Resumo}

O presente artigo procura identificar a hierarquia dos tratados internacionais sobre direitos humanos no direito brasileiro. Inicialmente, analisa os tratados sobre direitos humanos incorporados antes do advento da Emenda Constitucional $n^{\circ} 45 / 2004$ e as posições doutrinárias a respeito do tema existentes até então. Em seguida, estuda o conteúdo da Emenda Constitucional no 45/2004, as implicações dela sobre a hierarquia dos tratados sobre direitos humanos incorporados tanto antes quando depois de sua promulgação e os problemas interpretativos decorrentes do novo texto constitucional. Por fim, verifica a modificação da jurisprudência do Supremo Tribunal Federal a respeito do assunto ocorrida em dezembro de 2008 a realiza uma análise crítica dos novos entendimentos dos Ministros. Admite a possibilidade de coexistência de dois níveis hierárquicos distintos para os tratados sobre direitos humanos no Brasil e conclui que a forma de aprovação do tratado pelo legislativo é que determina o seu status hierárquico dentro do sistema jurídico.

Palavras-chave: Tratados. Direitos humanos. Hierarquia. Incorporação.

\section{Introdução}

Profundas foram as alterações trazidas pela Emenda Constitucional no 45 , de 8 de dezembro de 2004, no Direito brasileiro.

Ao acrescentar o $₫ 3^{\circ}$ ao art. $5^{\circ}$ da Constituição Federal, a referida emenda, que foi chamada pela mídia de "Reforma do Judiciário", previu a possibilidade de os tratados internacionais sobre direitos humanos serem equiparados às emendas

\footnotetext{
1 Este artigo está cadastrado no Digital Object Identifier System sob o número doi: 10.5102/ prismas.2010.07.1.08 Disponível em: <www.publicaçõesacadêmicas.uniceub.br>.

2 Mestrando em Direito e Políticas Públicas pelo UniCEUB - Centro Universitário de Brasília.
} 
constitucionais, desde que aprovados em dois turnos por cada uma das casas do Congresso Nacional, e por três quintos dos votos dos respectivos membros.

Antes da emenda, várias eram as opiniões a respeito do status hierárquico dos tratados internacionais sobre direitos humanos no ordenamento jurídico brasileiro, sendo que existem quatro correntes doutrinárias a respeito do assunto. ${ }^{3} \mathrm{De}$ qualquer forma, cada doutrinador, dentro da sua concepção pessoal, atribuía a todos os tratados internacionais sobre direitos humanos o mesmo nível hierárquico no direito interno, e a jurisprudência do Supremo Tribunal Federal reconhecia a todos eles o status de lei infraconstitucional.

Além da divergência, ainda não resolvida, a respeito da hierarquia normativa desses tratados, a emenda constitucional em questão criou, pelo menos, mais cinco problemas jurídicos que merecem a atenção de nossos intérpretes:

(1) A partir do momento em que a Constituição prevê a possibilidade de que os tratados internacionais sobre direitos humanos tenham status de emenda constitucional, e estabelece um rito procedimental para que isso ocorra, que status jurídico deve ser conferido aos tratados internacionais sobre direitos humanos já incorporados no direito interno e que não seguiram o procedimento agora previsto? Percebe-se facilmente que é preciso discutir a possibilidade de coexistirem dois níveis hierárquicos distintos para os tratados internacionais sobre direitos humanos no Brasil: os que foram incorporados antes da Emenda Constitucional $n^{\circ} 45 / 2004$ e aqueles que foram incorporados posteriormente a ela, e que foram aprovados na forma prevista pelo art. $5^{\circ}, \S 3^{\circ}$, da Constituição Federal.

(2) Optando-se pela possibilidade de coexistência de dois níveis hierárquicos distintos para esses diplomas jurídicos, seria possível submeter os tratados sobre direitos humanos incorporados no direito interno antes da Emenda Constitucional $n^{\circ} 45 / 2004$ novamente ao Congresso Nacional para, caso sejam agora aprovados na forma do art. $5^{\circ}, \S 3^{\circ}$, da Constituição Federal, alcançarem o status de emendas constitucionais?

(3) Se o tratado internacional sobre direitos humanos, após a referida emenda, para possuir hierarquia de emenda constitucional precisa ser aprovado

\footnotetext{
3 As quatro correntes doutrinárias serão explicadas no capítulo 2.
} 
em cada uma das casas do Congresso Nacional por maioria qualificada (três quintos) e em dois turnos, o tratado que obtiver a maioria dos votos, mas não atingir a quórum qualificado exigido, estaria rejeitado ou aprovado sem status de emenda constitucional? Na primeira hipótese, estaríamos reconhecendo que a Emenda Constitucional $n^{\circ} 45 / 2004$ dificultou sobremaneira a internalização dos tratados internacionais sobre direitos humanos, ao exigir quórum elevado para que isso ocorra; na segunda, estaríamos admitindo, mais uma vez, a possibilidade de coexistirem dois níveis hierárquicos distintos para os tratados internacionais sobre direitos humanos incorporados no Direito brasileiro.

(4) É possível ao Poder Executivo deixar de ratificar os tratados internacionais sobre direitos humanos aprovados pelo Congresso Nacional? Em caso negativo, como obrigar o Executivo a realizá-la ou controlar o prazo de ratificação?

(5) É possível ao Poder Executivo denunciar os tratados internacionais sobre direitos humanos aprovados pelo Congresso Nacional? Em caso positivo, quais os efeitos decorrentes da denúncia?

Como se vê, é de suma importância buscar a melhor resposta para as indagações ora formuladas, buscando construir, ao mesmo tempo, uma interpretação coerente em seu conjunto.

Também é necessário definir a hierarquia normativa dos tratados internacionais sobre direitos humanos, em face da Emenda Constitucional no 45/2004 e das novas interpretações que ela suscita. São esses os objetivos do presente trabalho.

Aproveita-se, ainda, a oportunidade, para analisar a evolução da jurisprudência do Supremo Tribunal Federal sobre a matéria.

\section{A disciplina dos tratados internacionais sobre direitos humanos anteriormente à Emenda Constitucional n 45/2004}

Antes da Emenda Constitucional no 45/2004, o único dispositivo constitucional que dispunha sobre os tratados internacionais era o art. $5^{\circ}, \S 2^{\circ}$, com a seguinte redação:

Os direitos e garantias expressos nesta Constituição não excluem outros decorrentes do regime e dos princípios 
por ela adotados, ou dos tratados internacionais em que a República Federativa do Brasil seja parte.

Note-se que essa norma constitucional não estabelece a hierarquia dos tratados internacionais (nem mesmo daqueles sobre direitos humanos), de forma que a discussão doutrinária e jurisprudencial a respeito do tema não tinha por base qualquer norma jurídica.

Alguns dos mais importantes tratados internacionais sobre direitos humanos em vigor foram incorporados no Direito brasileiro neste contexto: o Pacto Internacional sobre Direitos Econômicos, Sociais e Culturais, ${ }^{4} \mathrm{o}$ Pacto Internacional sobre Direitos Civis e Políticos ${ }^{5}$ e a Convenção Americana sobre Direitos Humanos (também conhecida como Pacto de São José da Costa Rica). ${ }^{6}$

A doutrina e a jurisprudência nacionais, então, procuraram definir o status jurídico dos tratados internacionais sobre direitos humanos no ordenamento brasileiro, e, segundo Galindo, ${ }^{7}$ surgiram quatro correntes sobre o tema. No julgamento, pelo plenário do Supremo Tribunal Federal, do Recurso Extraordinário n ${ }^{\text {o }}$ 466.343/SP, o Ministro Gilmar Mendes, em seu voto, ${ }^{8}$ também identificou as mesmas quatro posições, que são expostas a seguir.

\subsection{A posição que atribui hierarquia infraconstitucional aos tratados internacionais sobre direitos humanos ${ }^{9}$}

Esta corrente de pensamento considera que os tratados internacionais sobre direitos humanos, da mesma forma que os demais tratados internacionais, pos-

4 Aprovado pelo Decreto Legislativo no 226, de 12 de dezembro de 1991, e promulgado pelo Decreto $\mathrm{n}^{\circ}$ 591, de 6 de julho de 1992.

5 Aprovado pelo Decreto Legislativo no 226, de 12 de dezembro de 1991, e promulgado pelo Decreto $\mathrm{n}^{\circ}$ 592, de 6 de julho de 1992.

6 Aprovada pelo Decreto Legislativo no 27, de 26 de maio de 1992, e promulgada pelo Decreto $n^{\circ} 678$, de 6 de novembro de 1992.

7 GALINDO, George Rodrigo Bandeira. Tratados internacionais de direitos humanos e Constituição brasileira. Belo Horizonte: Del Rey, 2002. p. 251-284.

8 BRASIL. Supremo Tribunal Federal. Recurso Extraordinário no 466.343/SP. Ementário de Jurisprudência do Supremo Tribunal Federal, Brasília, v. 2.363, t. 6, p. 1.135-1.161, 5 jun. 2009.

9 Galindo denomina essa posição de "caráter meramente legal dos tratados de Direitos Humanos" GALINDO, George Rodrigo Bandeira. Tratados internacionais de direitos humanos 
suem status de lei federal (alguns autores chegam a especificar que o status é de lei ordinária), ${ }^{10}$ sendo passíveis, portanto, de controle de constitucionalidade. Dessa forma, tanto um tratado internalizado revoga a legislação infraconstitucional anterior que com ele não seja compatível, como uma lei federal posterior também tem o condão de revogar um tratado incorporado no direito interno que com ela não seja compatível, ${ }^{11}$ observado o princípio da especialidade. Na última hipótese, seria possível a responsabilização do Estado no plano internacional.

Após a promulgação da Constituição Federal de 1988, e antes do advento da Emenda Constitucional no 45/2004, o plenário do Supremo Tribunal Federal firmou o entendimento de que os tratados internacionais sobre direitos humanos possuem nível infraconstitucional, nos seguintes julgamentos: Habeas Corpus $\mathrm{n}^{\circ}$ 72.131/RJ (de 23/11/1995), Medida Cautelar na Ação Direta de Inconstitucionalidade $n^{\circ}$ 1.480/DF (de 04/09/1997), Habeas Corpus no 76.561/SP (de 27/05/1998), Recurso Extraordinário no 206.482/SP (de 27/05/1998), Recurso Ordinário em Habeas Corpus no 79.785/RJ (de 29/03/2000) e Habeas Corpus no 81.319/GO (de 24/04/2002). Importante salientar que o Tribunal já tinha esse entendimento antes mesmo da promulgação da Constituição Federal de 1988, desde o julgamento do Recurso Extraordinário no $80.004 / \mathrm{SE}$, ocorrido em $1^{\circ}$ de junho de 1977. Esse entendimento se manteve até o julgamento dos Habeas Corpus de no 87.585/TO e 92.566/SP e dos Recursos Extraordinários de n³ 349.703/RS e 466.343/SP, ocorrido em 3 de dezembro de 2008. ${ }^{12}$

e Constituição brasileira. Belo Horizonte: Del Rey, 2002. p. 256. O Ministro Gilmar Mendes a denomina de "tendência que reconhece o status de lei ordinária a esse tipo de documento internacional” BRASIL. Supremo Tribunal Federal. Recurso Extraordinário n 466.343/SP. Ementário de Jurisprudência do Supremo Tribunal Federal, Brasília, v. 2.363, t. 6, p. 1.137, 5 jun. 2009.

${ }^{10}$ Nesse sentido: “Assim, por exemplo, as normas do Pacto de São José da Costa Rica, a que adere o Brasil, não prevaleceriam sobre o direito constitucional positivo brasileiro. Teriam apenas a força de legislação ordinária” FERREIRA FILHO, Manoel Gonçalves. Direitos humanos fundamentais. 10. ed. São Paulo: Saraiva, 2008. p. 102. Com a mesma opinião: AMARAL JÚNIOR, José Levi Mello do. Reforma define status jurídico de tratados sobre direitos humanos. Disponível em: <http://www.conjur.com.br/2005jan26/reforma_define_status_juridico_tratados_internacionais $>$. Acesso em: 15 ago. 2009, p. 1.

${ }^{11} \mathrm{Na}$ forma do art. $2^{\circ}$ e seu $\$ 1^{\circ}$ da Lei de Introdução ao Código Civil Decreto-lei no 4.657 , de 4 de setembro de 1942 .

12 Trataremos dessa guinada jurisprudencial no capítulo 5 . 
Parte considerável da doutrina também se posicionou dessa maneira. ${ }^{13}$ Para Amaral Júnior:

Parece tranquilo concluir que o tratado internacional seja qual for a sua matéria, inclusive direitos humanos, ingressa no Direito brasileiro com status, com força, com hierarquia de lei. Mais especificamente, comporta-se como uma lei ordinária, porque a maioria requerida para a aprovação do decreto legislativo que recepciona o tratado é a mesma exigida para a aprovação de uma lei ordinária: a maioria simples (artigo 47 da Constituição de 1988). ${ }^{14}$

Segundo Ferreira Filho, no Direito brasileiro, três normas regem a matéria:

[...] primeira, jamais norma de tratado prevalece sobre a Constituição; segunda, a norma de tratado, desde que devidamente incorporada ao direito pátrio, prevalece sobre lei interna anterior; terceira, tendo, porém, o mesmo nível

${ }^{13}$ Rezek, numa clara análise da matéria, afirmou: "Recorde-se, de início, que o primado do direito das gentes sobre o direito nacional do Estado soberano é ainda hoje uma proposição doutrinária. Não há, em direito internacional positivo, norma assecuratória de tal primado. Descentralizada, a sociedade internacional contemporânea vê cada um de seus integrantes ditarem, no que lhe concerne, as regras de composição entre o direito internacional e o de produção doméstica. Resulta que para o Estado soberano a constituição nacional, vértice do ordenamento jurídico, é a sede de determinação da estatura da norma expressa em tratado. Dificilmente uma dessas leis fundamentais desprezaria, neste momento histórico, o ideal de segurança e estabilidade da ordem jurídica a ponto de subporse a si mesma ao produto normativo dos compromissos exteriores do Estado... Abstraída a constituição do Estado, sobrevive o problema da concorrência entre tratados e leis internas de estatura infraconstitucional. A solução, em países diversos, consiste em garantir prevalência aos tratados. Noutros, entre os quais o Brasil contemporâneo, garante-se-lhes apenas um tratamento paritário, tomadas como paradigma as leis nacionais e diplomas de grau equivalente". REZEK. Direito internacional público: curso elementar. 11. ed. São Paulo: Saraiva, 2008. p. 96-97. Ressalte-se, todavia, que embora o autor sempre tenha defendido a estatura infraconstitucional dos tratados em geral, inclusive dos tratados sobre direitos humanos, conforme voto por ele proferido na qualidade de Ministro do Supremo Tribunal Federal. BRASIL. Supremo Tribunal Federal. Habeas Corpus n 72.131/RJ. Ementário de Jurisprudência do Supremo Tribunal Federal, Brasília, v. 2.117, t. 40, p. 8.695, 1 ago. 2003), na última edição de sua obra, passou a defender a hierarquia constitucional desses tratados (vide nota $\mathrm{n}^{\circ} 28$ ).

${ }^{14}$ AMARAL JÚNIOR, José Levi Mello do. Reforma define status jurídico de tratados sobre direitos humanos. Disponível em: <http://www.conjur.com.br/2005-jan-26/reforma_define_status_juridico_tratados_internacionais>. Acesso em: 15 ago. 2009.p. 1. 
na hierarquia das leis que a norma interna, não prevalece sobre lei posterior (que pode revogá-la, derrogá-la etc.). ${ }^{15}$

Moraes ensina que:

As normas previstas nos atos, tratados, convenções ou pactos internacionais devidamente aprovadas pelo Poder Legislativo e promulgadas pelo Presidente da República, inclusive quando preveem normas sobre direitos fundamentais ingressam no ordenamento jurídico como atos normativos infraconstitucionais. ${ }^{16}$

Já Rodrigues esclarece que:

[...] os tratados internacionais de direitos humanos devem ser acolhidos, sim, mas desde que não ofereçam obstáculos às ordens constitucionais já existentes. Pois bem, se houver conflito de fonte constitucional com outra internacional, valerá a primeira, que só será alterada através dos meios ordinários nela prevista (Emenda Constitucional - art. 60). ${ }^{17}$

\subsection{A posição que atribui hierarquia supralegal aos tratados internacionais sobre direitos humanos}

Segundo esta corrente de pensamento, os tratados internacionais que versam sobre direitos humanos, apesar de não possuírem hierarquia constitucional (ou seja, devem se subordinar à Constituição, sendo passíveis, portanto, de controle de constitucionalidade), possuem um status superior à legislação infraconstitucional, que deve com ele se conformar. Dessa forma, o tratado, ao ser incorporado ao Direito brasileiro, revoga a legislação infraconstitucional que não seja com ele compatível, mas não poderá ser revogado por uma lei infraconstitucional posterior.

Foi o Ministro Sepúlveda Pertence quem inaugurou esse raciocínio no Brasil, ao proferir o seu voto, em sessão plenária do Supremo Tribunal Federal, no julgamento do Recurso Ordinário em Habeas Corpus n 79.785/RJ:

\footnotetext{
${ }^{15}$ FERREIRA FILHO, Manoel Gonçalves. Direitos humanos fundamentais. 10. ed. São Paulo: Saraiva, 2008. p. 101.

${ }^{16}$ MORAES, Alexandre de. Direito constitucional. 24. ed. São Paulo: Atlas, 2009. p. 691-692.

${ }^{17}$ RODRIGUES, Maurício Andreiuolo. Os tratados internacionais de proteção dos direitos humanos e a constituição. In: TORRES, Ricardo Lobo (Org.). Teoria dos direitos fundamentais, 2. ed. Rio de Janeiro: Renovar, 2001. p. 188.
} 
Assim como não o afirma em relação às leis, a Constituição não precisou dizer-se sobreposta aos tratados: a hierarquia está ínsita em preceitos inequívocos seus, como os que submetem a aprovação e a promulgação das convenções ao processo legislativo ditado pela Constituição e menos exigente que o das emendas a ela e aquele que, em conseqüência, explicitamente admite o controle da constitucionalidade dos tratados (CF, art. 102, III, b).

$[\ldots]$

$\mathrm{Na}$ ordem interna, direitos e garantias fundamentais o são, com grande freqüência, precisamente porque - alçados ao texto constitucional - se erigem em limitações positivas ou negativas ao conteúdo das leis futuras, assim como à recepção das anteriores à Constituição (cf. HANS KELSEN, p. 255).

Se assim é, à primeira vista, parificar às leis ordinárias os tratados a que alude o art. $5^{\circ}, \S 2^{\circ}$, da Constituição, seria esvaziar de muito do seu sentido útil à inovação, que, malgrado os termos equívocos do seu enunciado, traduziu uma abertura significativa ao movimento de internacionalização dos direitos humanos.

Ainda sem certezas suficientemente amadurecidas, tendo assim... a aceitar a outorga de força supralegal às convenções de direitos humanos, de modo a dar aplicação direta às suas normas - até, se necessário, contra a lei ordinária - sempre que, sem ferir a Constituição, a complementem, especificando ou ampliando os direitos e garantias dela constantes". ${ }^{18}$

Para Galindo, que, todavia, não adere a essa corrente de pensamento, ela:

[...] leva em consideração as especificidades dos tratados de Direitos Humanos, tratando-os de modo diverso aos demais tratados internacionais. Aqueles gozariam de supralegalidade, estando necessariamente submetidos à supremacia constitucional. ${ }^{19}$

\footnotetext{
${ }^{18}$ BRASIL. Supremo Tribunal Federal. Recurso Ordinário em Habeas Corpus n 79.785/RJ. Ementário de Jurisprudência do Supremo Tribunal Federal, Brasília, v. 2.092, t. 2, p. 300301, 22 nov. 2002.

${ }^{19}$ GALINDO, George Rodrigo Bandeira. Tratados internacionais de direitos humanos e Constituição brasileira. Belo Horizonte: Del Rey, 2002. p. 268.
} 


\subsection{A posição que atribui hierarquia constitucional aos tratados internacionais sobre direitos humanos}

Para esta corrente de pensamento, o art. $5^{\circ}, \$ 2^{\circ}$, da Constituição Federal, segundo o qual “os direitos e garantias expressos nesta Constituição não excluem outros decorrentes do regime e dos princípios por ela adotados, ou dos tratados internacionais em que a República Federativa do Brasil seja parte”, incorpora todos os direitos humanos previstos nos tratados internalizados ao texto constitucional, de forma que os tratados internacionais sobre direitos humanos têm natureza materialmente constitucional, passando a integrar o chamado "bloco de constitucionalidade".

Assim, um tratado internacional sobre direitos humanos incorporado ao ordenamento jurídico interno torna inconstitucional toda a legislação infraconstitucional que com ele não seja compatível. Por outro lado, não seria possível a exclusão dos direitos humanos internalizados por via do tratado do rol de direitos constitucionais nem mesmo por uma emenda constitucional posterior, pois os direitos e garantias individuais são cláusulas pétreas (art. 60, $₫ 4^{\circ}$, inciso IV, da Constituição Federal).

Diversos são os doutrinadores que se alinham a essa vertente de raciocínio. Segundo Cançado Trindade:

[...] a especificidade e o caráter especial dos tratados de proteção internacional dos direitos humanos encontram-se, com efeito, reconhecidos e sancionados pela Constituição Brasileira de 1988: se, para os tratados internacionais em geral, se tem exigido a intermediação pelo Poder Legislativo de ato com força de lei de modo a outorgar as suas disposições vigência ou obrigatoriedade no plano do ordenamento jurídico interno, distintamente no caso dos tratados de proteção internacional dos direitos humanos em que o Brasil é Parte, os direitos fundamentais neles garantidos passam, consoante os artigos 5(2) e 5(1) da Constituição Brasileira de 1988, a integrar o elenco dos direitos constitucionalmente consagrados e direta e imediatamente exigíveis no plano do ordenamento jurídico interno. ${ }^{20}$

${ }^{20}$ CANÇADO TRINDADE, Antônio Augusto. Tratado de direito internacional dos direitos humanos. 2. ed. Porto Alegre: S. A. Fabris, 2003. v. 1. p. 513. 
Para Galindo:

[...] deve-se defender a posição de que os tratados possuem estatura hierárquica constitucional, disto advindo algumas conseqüências: a) o art. $5^{\circ}, \S 2^{\circ}$ abrange todos os tratados versando sobre Direitos Humanos, e não apenas os consagradores de Direitos Individuais e Coletivos; b) tanto o Direito Costumeiro como o Direito não - obrigatório de grande relevância - como poderia ser configurada a Declaração Universal dos Direitos do Homem - são abrangidos pela cláusula constitucional; c) os tratados de Direitos Humanos possuem o mesmo caráter dos Direitos Fundamentais consagrados expressamente na Constituição. ${ }^{21}$

Mazzuoli ensina que o art. $5^{\circ}, \S 2^{\circ}$, da Constituição Federal, leva a entender que "os tratados internacionais de direitos humanos ratificados pelo Brasil têm índole e nível constitucionais, além de aplicação imediata, não podendo ser revogados por lei ordinária posterior” ${ }^{22}$

Segundo Piovesan:

[...] ao prescrever que 'os direitos e garantias expressos na Constituição não excluem outros direitos decorrentes dos tratados internacionais', a contrario sensu, a Carta de 1988 está a incluir, no catálogo de direitos constitucionalmente protegidos, os direitos enunciados nos tratados internacionais em que o Brasil seja parte. Esse processo de inclusão implica a incorporação pelo Texto Constitucional de tais direitos. ${ }^{23}$

A referida autora também argumenta que:

[...] em favor da hierarquia constitucional dos direitos enunciados em tratados internacionais, outro argumento se acrescenta: a natureza materialmente constitucional dos direitos fundamentais [...] Os direitos internacionais integrariam, assim, o chamado 'bloco de constitucionalidade', densificando a regra constitucional positivada no $\$ 2^{\circ}$ do art. $5^{\circ}$, caracterizada como cláusula constitucional aberta. ${ }^{24}$

${ }^{21}$ GALINDO, George Rodrigo Bandeira. Tratados internacionais de direitos humanos e Constituição brasileira. Belo Horizonte: Del Rey, 2002. p. 410.

${ }^{22}$ MAZZUOLI, Valério de Oliveira. Curso de direito internacional público. 3. ed. São Paulo: RT, 2008. p. 750.

${ }^{23}$ PIOVESAN, Flávia. Direitos humanos e o direito constitucional internacional. 10. ed. São Paulo: Saraiva, 2009. p. 52.

${ }^{24}$ PIOVESAN, Flávia. Direitos humanos e o direito constitucional internacional. 10. ed. São Paulo: Saraiva, 2009. p. 54-55. 
Para Sarlet:

[...] nunca é demais lembrar que a tese da paridade entre a Constituição e os tratados de direitos humanos é anterior à EC no 45 e encontra sustentação já no teor do $\$ 2^{\circ}$ do mesmo artigo, que, na sua condição de norma inclusiva, consagrando a abertura material do catálogo constitucional de direitos fundamentais, já vinha... sendo interpretado como recepcionando os direitos humanos oriundos de textos internacionais na condição de materialmente constitucionais. De resto, há que enfatizar sempre que a condição de direitos fundamentais é absolutamente incompatível com uma hierarquia normativa infraconstitucional, visto que direitos fundamentais são sempre direitos constitucionais e não podem estar à disposição plena do legislador ordinário. ${ }^{25}$

Ele ainda acrescenta que essa tese:

[...] é a que mais se harmoniza com a especial dignidade jurídica e axiológica dos direitos fundamentais na ordem jurídica interna e internacional, constituindo, ademais, pressuposto indispensável à construção e consolidação de um autêntico direito constitucional internacional dos direitos humanos, resultado da interpenetração cada vez maior entre os direitos fundamentais constitucionais e os direitos humanos dos instrumentos jurídicos internacionais. ${ }^{26}$

No Supremo Tribunal Federal, antes do advento da Emenda Constitucional $n^{\circ} 45 / 2004$, apenas o Ministro Carlos Velloso professava esse entendimento. ${ }^{27}$

${ }^{25}$ SARLET, Ingo Wolfgang. A abertura material do catálogo constitucional dos direitos fundamentais e os tratados internacionais em matéria de direitos humanos: conteúdo e significado os parágrafos $2^{\circ}$ e $3^{\circ}$ do art. $5^{\circ}$ da Constituição Federal de 1988. In: ROCHA, Maria Elizabeth Guimarães Teixeira; MEYER-PFLUG, Samantha Ribeiro (Coord.). Lições de direito constitucional em homenagem ao professor Jorge Miranda. Rio de Janeiro: Forense, 2008. p. 100.

${ }^{26}$ SARLET, Ingo Wolfgang. A eficácia dos direitos fundamentais: uma teoria geral dos direitos fundamentais na perspectiva constitucional. 10. ed. Porto Alegre: Livraria do Advogado, 2009. p. 124.

${ }^{27}$ Conforme os seguintes votos por ele proferidos: BRASIL. Supremo Tribunal Federal. Habeas Corpus n ${ }^{\circ} 72.131 / R J$. Ementário de Jurisprudência do Supremo Tribunal Federal, v. 2.117 , t. 40 , p. 8.719-8.720, $1^{\circ}$ ago. 2003; BRASIL. Supremo Tribunal Federal. Medida Cautelar na Ação Direta de Inconstitucionalidade no 1.480/DF. Ementário de Jurisprudência do Supremo Tribunal Federal, v. 2.031, t. 2, p. 316-319, 324-326 e 332, 18 maio 2001; BRASIL. Supremo Tribunal Federal. Recurso Extraordinário no 206.482/SP. Ementário 


\subsection{A posição que atribui hierarquia supraconstitucional aos tratados internacionais sobre direitos humanos}

Esta corrente de pensamento considera que os tratados internacionais sobre direitos humanos, em virtude do disposto no mesmo art. $5^{\circ}, \S 2^{\circ}$, da Constituição Federal, prevalecem sobre as normas constitucionais, devendo estas se curvarem às normas internacionais.

Dessa forma, um tratado internacional sobre direitos humanos incorporado ao ordenamento jurídico vincula toda a legislação interna, inclusive as normas constitucionais, não sendo possível uma norma constitucional posterior revogar uma norma internacional constitucionalizada (ou seja, incorporada ao rol dos direitos constitucionalizados por um tratado sobre direitos humanos).

No Brasil, o único defensor desse posicionamento é Mello, para quem,

A Constituição de 1988 no $\$ 2^{\circ}$ do art. $5^{\circ}$ constitucionalizou as normas de direitos humanos consagradas nos tratados. Significando isto que as referidas normas são normas constitucionais, como diz Flávia Piovesan... Contudo sou ainda mais radical no sentido de que a norma internacional prevalece sobre a norma constitucional, mesmo naquele caso em que uma norma constitucional posterior tente revogar uma norma internacional constitucionalizada. ${ }^{28}$

\section{A Emenda Constitucional n. 45/2004}

A Emenda Constitucional no 45, de 8 de dezembro de 2004, também chamada de "Reforma do Judiciário", acrescentou o $\$ 3^{\circ}$ ao art. $5^{\circ}$ da Constituição Federal, com a seguinte redação:

Os tratados e convenções internacionais sobre direitos humanos que forem aprovados, em cada Casa do Congresso Nacional, em dois turnos, por três quintos dos votos dos

de Jurisprudência do Supremo Tribunal Federal, v. 2.122, t. 4, p. 699-700, 5 set. 2003; e BRASIL. Supremo Tribunal Federal. Recurso Ordinário em Habeas Corpus no 79.785/ RJ. Ementário de Jurisprudência do Supremo Tribunal Federal, v. 2.092, t. 2, p. 319-320, 22 nov. 2002.

${ }^{28}$ MELLO, Celso de Albuquerque. $\mathrm{O} \$ 2^{\circ}$ do art. $5^{\circ}$ da Constituição Federal. In: TORRES, Ricardo Lobo (Org.). Teoria dos direitos fundamentais. 2. ed. Rio de Janeiro: Renovar, 2001. p. 25. 
respectivos membros, serão equivalentes às emendas constitucionais.

Quando a Constituição Federal passou a prever a possibilidade de os tratados que versam sobre direitos humanos serem internalizados com status de emenda constitucional, por decorrência lógica, ela também deixou claro que os demais tratados sobre a matéria, que não foram incorporados no Direito interno pelo rito especial agora previsto (que exige o mesmo procedimento de aprovação e quórum qualificado exigido para a aprovação das emendas constitucionais - art. $60, \S 2^{\circ}$ ), não podem ter a mesma hierarquia. ${ }^{29} \mathrm{Ou}$ seja, somente os instrumentos jurídicos internacionais aprovados pelo Congresso Nacional na forma de emendas constitucionais podem ter status de normas constitucionais. ${ }^{30}$

Dessa maneira, a referida emenda constitucional nenhuma influência pode exercer sobre a hierarquia dos tratados internacionais sobre direitos humanos que já haviam sido incorporados no Direito brasileiro antes de sua promulgação. Esses diplomas jurídicos continuam, portanto, com o mesmo grau hierárquico a eles atribuído antes da vigência da Emenda Constitucional em foco. ${ }^{31}$

${ }^{29}$ Não é esse o entendimento de Rezek, que, na última edição de sua obra, modificando seu entendimento anterior (vide nota $n^{\circ} 12$ ), esclarece que "é sensato crer que ao promulgar esse parágrafo na Emenda constitucional 45, de 8 de dezembro de 2004, sem nenhuma ressalva abjuratória dos tratados sobre direitos humanos outrora concluídos mediante processos simples, o Congresso constituinte os elevou à categoria dos tratados de nível constitucional". REZEK, José Francisco. Direito internacional público: curso elementar. 11. ed. São Paulo: Saraiva, 2008. p. 103.

${ }^{30}$ Esse é o entendimento de Amaral Júnior: "Portanto, os tratados ou convenções internacionais sobre direitos humanos que sejam - ou melhor, desde que sejam - recepcionados nos termos do processo de aprovação das emendas constitucionais (art. 60 da Constituição de 1988) terão o status das normas constitucionais. Por outro lado, os tratados ou convenções internacionais sobre direitos humanos recepcionados segundo o mecanismo usual de recepção - aquele por meio de decreto legislativo - terão, ou melhor, continuarão a ter, induvidosamente, força de lei ordinária” AMARAL JÚNIOR, José Levi Mello do. Reforma define status jurídico de tratados sobre direitos humanos. Disponível em <http://www.conjur.com.br/2005-jan-26/reforma_define_status_juridico_tratados_internacionais>. Acesso em: 15 ago. 2009. p. 2.

${ }^{31}$ Segundo Amaral Júnior, "a Reforma do Poder Judiciário sepultou a possibilidade de ser reconhecido status constitucional aos tratados - passados e futuros - que não sejam internalizados por meio de processo análogo àquele das emendas constitucionais (ou que venham a ser submetidos a esse processo)". AMARAL JÚNIOR. Reforma sepulta chance de status constitucional automático a tratados. Disponível em: <http://www.conjur.com. br/2005-fev-01/reforma_nega_status_constitucional_automatico_tratados $>$. Acesso em: 15 ago. 2009. p. 2. 


\section{A disciplina dos tratados internacionais sobre direitos humanos após a Emenda Constitucional n. 45/2004}

Quanto aos instrumentos jurídicos internacionais que forem aprovados pelo Congresso Nacional na forma do art. $5^{\circ}, \$ 3^{\circ}$, da Constituição Federal, não há dúvida: eles possuirão hierarquia constitucional.

Mas é preciso reconhecer que a Emenda Constitucional no 45/2004 cria algumas dificuldades interpretativas, em virtude da coerência que deve possuir o sistema jurídico. Inicialmente, é necessário discutir a possibilidade de coexistirem dois níveis hierárquicos distintos para os tratados internacionais sobre direitos humanos no Brasil. Em segundo lugar, é preciso questionar a possibilidade de um instrumento jurídico internacional que versa sobre direitos humanos, e já incorporado no ordenamento jurídico nacional antes do advento da mencionada emenda constitucional, ser submetido novamente ao Congresso Nacional para efeito de alcançar o status de norma constitucional. Em terceiro lugar, é necessário analisar a possibilidade de um tratado internacional sobre direitos humanos ser internalizado, após a vigência do art. $5^{\circ}, \S 3^{\circ}$, da Constituição Federal, caso não alcance o quórum qualificado ali exigido, por maioria simples, e com status de norma infraconstitucional. Em quarto lugar, é preciso examinar o problema da ausência de ratificação dos tratados sobre direitos humanos aprovados pelo Congresso Nacional. Por fim, é necessário averiguar a possibilidade de denúncia dos tratados internacionais de direitos humanos já incorporados, bem como os efeitos dela decorrentes.

\subsection{O problema da possibilidade de coexistência de dois níveis hierárquicos distintos para os tratados internacionais sobre direitos humanos}

Como já analisado no capítulo 2 deste trabalho, antes da Emenda Constitucional no 45/2004, os doutrinadores se dividiam em quatro correntes distintas ao definir a hierarquia dos tratados internacionais sobre direitos humanos no ordenamento jurídico brasileiro. Porém, nenhum doutrinador admitia a possibilidade de que tratados sobre direitos humanos distintos pudessem ter status jurídicos diversos.

Todavia, com a promulgação da referida emenda constitucional, essa realidade passou a existir. Ao exigir o mesmo rito procedimental e quórum qualificado das emendas constitucionais para atribuir status constitucional aos tratados interna- 
cionais sobre direitos humanos, o art. $5^{\circ}, \S 3^{\circ}$, da Constituição Federal, deixou sem sustentação jurídica aqueles que atribuíam hierarquia constitucional aos instrumentos jurídicos internacionais já incorporados por maioria simples, e cuja aprovação havia acontecido em turno único. A esses tratados, por terem sido aprovados pelo Congresso Nacional por meio do mesmo rito procedimental da lei ordinária, e com o mesmo quórum exigido por essa espécie normativa, só se pode atribuir o status infraconstitucional. É o caso do Pacto Internacional sobre Direitos Econômicos, Sociais e Culturais, ${ }^{32}$ do Pacto Internacional sobre Direitos Civis e Políticos ${ }^{33}$ e da Convenção Americana sobre Direitos Humanos (Pacto de São José da Costa Rica). ${ }^{34}$

E já existe um tratado internacional sobre direitos humanos aprovado pelo Congresso Nacional com status de Emenda Constitucional: trata-se da Convenção sobre os Direitos das Pessoas com Deficiência e seu Protocolo Facultativo. ${ }^{35}$

Atualmente, portanto, convivem em nosso ordenamento jurídico dois níveis hierárquicos de tratados internacionais sobre direitos humanos: (1) aqueles incorporados com o rito procedimental e quórum exigidos para a aprovação das leis ordinárias e (2) aqueles incorporados com o rito procedimental e quórum qualificado exigidos para a aprovação das emendas constitucionais. Por decorrência lógica, os primeiros possuem status infraconstitucional e os últimos, status constitucional.

Alguns doutrinadores entendem que essa diferenciação não é possível, e que todos os tratados sobre direitos humanos, por terem a mesma origem, devem possuir o mesmo nível hierárquico. ${ }^{36}$

Todavia, é importante observar que todo instrumento jurídico internacional, para ter validade no território nacional, precisa ser incorporado ao nosso or-

32 Aprovado pelo Decreto Legislativo $\mathrm{n}^{\circ} 226$, de 12 de dezembro de 1991, e promulgado pelo Decreto no 591, de 6 de julho de 1992.

33 Aprovado pelo Decreto Legislativo ${ }^{\circ}$ 226, de 12 de dezembro de 1991, e promulgado pelo Decreto no 592, de 6 de julho de 1992.

${ }^{34}$ Aprovada pelo Decreto Legislativo $\mathrm{n}^{\circ}$ 27, de 26 de maio de 1992, e promulgada pelo Decreto $n^{\circ} 678$, de 6 de novembro de 1992.

${ }_{35}$ Aprovados na forma do art. $5^{\circ}, \S 3^{\circ}$, da Constituição Federal, pelo Decreto Legislativo ${ }^{\circ}$ 186, de 9 de julho de 2008.

${ }^{36}$ Para Piovesan, "há que afastar o entendimento segundo o qual, em face do $\$ 3^{\circ}$ do art. $5^{\circ}$, todos os tratados de direitos humanos já ratificados seriam recepcionados como lei federal, pois não teria obtido o quorum qualificado de três quintos, demandado pelo aludido parágrafo... Reitere-se que, por força do art. $5^{\circ}, \S 2^{\circ}$, todos os tratados de direitos humanos, 
denamento jurídico. Os tratados internacionais não têm validade automática no país por decisão do Poder Executivo. Ao contrário, precisam ser aprovados pelo Congresso Nacional, nos termos do art. 49, inciso I, da Constituição Federal. Dessa maneira, a forma pela qual o legislativo aprova cada tratado sobre direitos humanos é fundamental para se averiguar a respectiva hierarquia.

Essa é a interpretação mais condizente com a atual redação do art. $5^{\circ}, \S 3^{\circ}$, da nossa Lei Maior. Reconheça-se que o ideal seria que o próprio Congresso Nacional, desde sempre (ou seja, mesmo antes do advento da Emenda Constitucional $n^{\circ} 45 / 2004$ ), ao apreciar cada tratado internacional (e não somente os que versam sobre direitos humanos), optasse pela forma de aprovação mais adequada, decidindo acerca do status jurídico de incorporação. ${ }^{37}$ Essa decisão sempre foi de competência exclusiva do Congresso Nacional, em decorrência do disposto no art. 49, inciso I, da Constituição Federal. Todavia, essa possibilidade nunca foi exercitada antes da Emenda Constitucional no 45/2004, e foi preciso inserir na Constituição uma norma prevendo expressamente a incorporação dos tratados internacionais sobre direitos humanos como emendas constitucionais para que o Congresso Nacional vislumbrasse a hipótese. E agora, diante dessa norma (art. $5^{\circ}, \S 3^{\circ}$ ), é preciso admitir que não é mais possível ao Congresso Nacional atribuir hierarquia constitucional a um tratado, a não ser que ele verse sobre direitos humanos. Ou seja, o art. $5^{\circ}, \S 3^{\circ}$, da Constituição Federal, acabou limitando os poderes do Congresso Nacional.

\subsection{0 problema da possibilidade de nova submissão dos tratados internacionais sobre direitos humanos incorporados antes da Emenda Constitucional n. 45/2004 ao crivo do Congresso Nacional}

A partir do momento em que a Constituição Federal passou a prever expressamente a possibilidade de incorporação dos tratados internacionais sobre direitos humanos com hierarquia de Emenda Constitucional (e muito embora essa

independentemente do quorum de sua aprovação, são materialmente constitucionais, compondo o bloco de constitucionalidade. O quorum qualificado está tão-somente a reforçar tal natureza, ao adicionar um lastro formalmente constitucional aos tratados ratificados, propiciando a 'constitucionalização formal' dos tratados de direitos humanos no âmbito jurídico interno" PIOVESAN, Flávia. Direitos humanos e o direito constitucional internacional. 10. ed. São Paulo: Saraiva, 2009. p. 72.

${ }^{37}$ Vide o item 4.3. 
possibilidade já existisse anteriormente, pois não dependia de previsão expressa), é preciso debater, em nome da coerência do sistema jurídico, a possibilidade de nova submissão dos tratados já incorporados com hierarquia infraconstitucional, na vigência do sistema anterior à Emenda Constitucional no 45/2004, ao Congresso Nacional, para que o legislativo, querendo, possa conferir a esses diplomas jurídicos status de norma constitucional.

A vantagem dessa proposta é que ela possibilita ao Congresso Nacional atribuir ao instrumento jurídico já internalizado um status jurídico superior, que, à época da internalização, não foi objeto de análise por parte do legislativo (embora a atribuição desse status constitucional fosse possível àquela época). Assim, tratados sobre direitos humanos como o Pacto Internacional sobre Direitos Econômicos, Sociais e Culturais, o Pacto Internacional sobre Direitos Civis e Políticos e a Convenção Americana sobre Direitos Humanos (Pacto de São José da Costa Rica), diplomas jurídicos da maior relevância (e provavelmente mais importantes e abrangentes do que muitos dos tratados que venham, a partir de agora, a ser aprovados na forma de Emenda Constitucional), poderiam ter o seu status jurídico reavaliado pelo legislativo. ${ }^{38}$

Com isso, seria possível ao Congresso Nacional analisar o status jurídico dos tratados internacionais sobre direitos humanos aprovados antes da Emenda Constitucional $n^{\circ} 45 / 2004$, verificando, caso a caso, quais merecem ser alçados ao nível de norma constitucional e quais devem continuar com o nível de norma infraconstitucional. Evidentemente, os tratados já incorporados que, num eventual reexame, não consigam atingir o quórum qualificado agora exigido pelo art. $5^{\circ}$, $\$ 3^{\circ}$, da Constituição Federal, continuariam com o status jurídico original, a eles conferido no momento da internalização.

De qualquer forma, o importante é que o legislativo teria a possibilidade de corrigir algumas distorções na hierarquia dos tratados internacionais sobre direitos humanos dentro do ordenamento jurídico nacional, provocadas pela mudança na forma de incorporação.

\footnotetext{
${ }^{38}$ Esse é o entendimento de Amaral Júnior: "Por outro lado, nada impede que um tratado já internalizado seja novamente deliberado, agora na forma do parágrafo $3^{\circ}$ do art. $5^{\circ}$ combinado com o parágrafo $2^{\circ}$ do art. 60, ambos da Constituição" AMARAL JÚNIOR. Reforma sepulta chance de status constitucional automático a tratados. Disponível em: $<$ http://www.conjur.com.br/2005-fev-01/reforma_nega_status_constitucional_automatico_tratados>. Acesso em: 15 ago. 2009. p. 2.
} 
Quanto aos tratados internacionais sobre direitos humanos incorporados na vigência da Emenda Constitucional nº 45/2004, não há necessidade de reexame (embora também não haja vedação), pois o Congresso Nacional já apreciou a possibilidade de sua internalização com status de norma constitucional.

\subsection{0 problema da possibilidade de um tratado internacional sobre direitos humanos ser incorporado, após a Emenda Constitucional n. 45/2004, por maioria simples, mas sem status constitucional}

Se por um lado o art. $5^{\circ}, \S 3^{\circ}$, da Constituição Federal, exigiu procedimento e quórum especiais para conferir status constitucional aos tratados internacionais sobre direitos humanos, por outro não vedou a internalização desses instrumentos jurídicos por meio da forma antiga, sem as novas exigências, mas com status infraconstitucional.

Assim, o tratado que não atingir a maioria qualificada exigida no novo dispositivo, mas que obtiver a maioria simples dos votos pela sua aprovação no primeiro turno de votação, em cada casa do Congresso Nacional, não estará rejeitado, mas sim aprovado, embora sem status de Emenda Constitucional. ${ }^{39}$ Evidentemente, o tratado que não obtiver sequer maioria simples no primeiro turno de votação, em qualquer das casas, estará rejeitado.

Se não fosse assim, a Emenda Constitucional no 45/2004 teria dificultado sobremaneira a internalização dos tratados internacionais sobre direitos humanos,

\footnotetext{
${ }^{39}$ Nesse sentido: “As duas vias convivem. O parágrafo 3 do art. 5 da Constituição de 1988 faculta a recepção dos tratados e convenções internacionais sobre direitos humanos por intermédio de uma Emenda Constitucional e não exclui a recepção pelo mecanismo tradicional, por meio de um decreto legislativo" AMARAL JÚNIOR, José Levi Mello do. Reforma define status jurídico de tratados sobre direitos humanos. Disponível em $<\mathrm{http}: / /$ www.conjur.com.br/2005-jan-26/reforma_define_status_juridico_tratados_internacionais $>$. Acesso em: 15 ago. 2009. p. 2; "Outro aspecto digno de nota... diz respeito ao caráter compulsório ou facultativo da adoção do procedimento mais rigoroso das emendas constitucionais, especialmente em face da redação do dispositivo ('os tratados que forem incorporados...), que, no mínimo, dá ensejo a tal dúvida e sustenta a adoção do entendimento que a incorporação mediante o procedimento das emendas poderia ser opcional" SARLET, Ingo Wolfgang. A eficácia dos direitos fundamentais: uma teoria geral dos direitos fundamentais na perspectiva constitucional. 10. ed. Porto Alegre: Livraria do Advogado, 2009. p. 130.
} 
ao exigir sempre o quórum qualificado de três quintos dos membros de cada casa do Congresso Nacional, e em dois turnos de votação. ${ }^{40}$

Portanto, e mais uma vez, está sendo admitida a possibilidade de coexistirem dois níveis hierárquicos distintos para os tratados internacionais sobre direitos humanos incorporados no Direito brasileiro.

\subsection{0 problema da ausência de ratificação dos tratados internacionais sobre direitos humanos}

Ratificação é "o ato unilateral com que a pessoa jurídica de direito internacional, signatária de um tratado, exprime definitivamente, no plano internacional, sua vontade de obrigar-se". ${ }^{41}$

Como o tratado é um acordo formal entre pessoas jurídicas de direito internacional público (aí incluídos os Estados soberanos e as organizações internacionais), cada Estado tem liberdade para ratificar ou não determinado tratado ou a ele aderir. ${ }^{42}$

Portanto, é plenamente possível ao Poder Executivo, no uso da competência privativa prevista no art. 84, inciso VIII, da Constituição Federal, mesmo após a respectiva aprovação pelo Congresso Nacional, deixar de ratificar o tratado.

40 "Tal argumento assume ainda maior relevo em se considerando que - sob o ponto de vista da forma - a incorporação dos tratados em matéria de direitos humanos... se tornou mais dificultada, o que, em princípio, poderia ser considerado como contraditório, considerando a abertura material consagrada no art. $5^{\circ}, \S 2^{\circ}$, e o princípio (fundamental) da prevalência dos direitos humanos no plano das relações internacionais do Brasil estabelecida no artigo $4^{\circ}$ da nossa Lei Fundamental" SARLET, Ingo Wolfgang. A eficácia dos direitos fundamentais: uma teoria geral dos direitos fundamentais na perspectiva constitucional. 10. ed. Porto Alegre: Livraria do Advogado, 2009. p. 130.

${ }^{41}$ REZEK, José Francisco. Direito internacional público: curso elementar. 11. ed. São Paulo: Saraiva, 2008. p. 50.

42 "A adesão é uma forma de expressão definitiva do consentimento do Estado em relação ao tratado internacional. Sua natureza jurídica não difere daquela da ratificação: também aqui o que temos é manifestação firme da vontade de ingressar no domínio jurídico do tratado. $\mathrm{O}$ aderente é, em princípio, um Estado que não negociou nem assinou o pacto - e que assim não pode ratificá-lo -, mas que, tomado de interesse por ele, decide tornar-se parte, havendo-se antes certificado da possibilidade do ingresso por adesão". REZEK, José Francisco. Direito internacional público: curso elementar. 11. ed. São Paulo: Saraiva, 2008. p. 85. 
Assim como não há meio de obrigar o Poder Executivo, após a aprovação legislativa, a ratificar o tratado ou formalizar a respectiva adesão, também não é possível ao Poder Legislativo, em face da inexistência de mecanismo constitucional expresso, efetuar qualquer espécie de controle sobre o prazo de ratificação. Aliás, exceto se previsto no próprio tratado, não há prazo máximo para a ratificação (ou adesão).

Numa hipótese, todavia, a ausência de ratificação somente teria influência no plano internacional, sendo irrelevante para o direito interno: os tratados sobre direitos humanos que conferem direitos e garantias individuais, aprovados pelo Congresso Nacional na forma do art. $5^{\circ}, \S 3^{\circ}$, da Constituição Federal, por serem equivalentes às emendas constitucionais, mesmo antes de ratificados, já estariam vigorando no plano interno na condição de normas constitucionais, com a simples promulgação, pelas Mesas da Câmara dos Deputados e do Senado Federal (art. 60, $\left.\$ 3^{\circ}, \mathrm{CF}\right)$, do Decreto Legislativo que os aprovou. ${ }^{43}$

\subsection{0 problema da possibilidade de denúncia dos tratados internacionais sobre direitos humanos}

Denúncia é o ato pelo qual "manifesta o Estado sua vontade de deixar de ser parte no acordo internacional".44

Como o tratado é um acordo formal entre pessoas jurídicas de direito internacional público (aí incluídos os Estados soberanos e as organizações internacionais), da mesma maneira que cada Estado tem liberdade para ratificar ou não determinado tratado, ou a ele aderir, ${ }^{45}$ também poderá, a qualquer momento, denunciá-lo. Todavia,

[...] tratados existem que, por sua própria natureza, são imunes à denúncia unilateral. Tal é, seguramente, o caso

\footnotetext{
${ }^{43}$ Foi o que aconteceu com a Convenção sobre os Direitos das Pessoas com Deficiência e seu Protocolo Facultativo, aprovados pelo Decreto Legislativo no 186, de 9 de julho de 2008.

${ }^{44}$ REZEK, José Francisco. Direito internacional público: curso elementar. 11. ed. São Paulo: Saraiva, 2008. p. 107.

45 "Enfatize-se que os tratados são, por excelência, expressão de consenso. Apenas pela via do consenso podem os tratados criar obrigações legais, uma vez que Estados soberanos, ao aceitá-los, comprometem-se a respeitá-los" PIOVESAN, Flávia. Direitos humanos e o direito constitucional internacional. 10. ed. São Paulo: Saraiva, 2009. p. 46.
} 
dos tratados de vigência estática. Não se compreende que a vontade singular de uma das partes possa fazer reverter certo pacto de cessão territorial onerosa, ou de definição de fronteira comum. Esses tratados, mais expressivos de um título jurídico que de normas operacionais de conduta, costumam ser bilaterais. No plano coletivo, dificilmente se encontrarão compromissos de vigência estática. ${ }^{46}$

Assim, como os tratados internacionais sobre direitos humanos são compromissos multilaterais (e não bilaterais), a princípio, são denunciáveis. E a formalização da denúncia cabe ao mesmo representante do Estado que ratificou o tratado ou a ele aderiu. Ou seja, no Brasil, a denúncia é de competência privativa do Presidente da República (art. 84, VIII, CF). Discute-se na doutrina, todavia, se para formalizar a denúncia o Presidente da República necessitaria de autorização do Congresso Nacional, em face do art. 49, inciso I, da Constituição Federal.

De qualquer forma, e em qualquer caso, tratando-se de diplomas internacionais multilaterais que versam sobre direitos humanos, a denúncia é sempre possível. $^{47}$

Numa hipótese, todavia, a denúncia somente produziria efeitos no plano internacional, sendo irrelevante para o Direito interno: os tratados sobre direitos humanos que conferem direitos e garantias individuais, aprovados pelo Congresso Nacional na forma do art. $5^{\circ}, \S 3^{\circ}$, da Constituição Federal, por serem equivalentes às emendas constitucionais, não deixariam de vigorar no plano interno em virtude da denúncia. Além disso, também não seria possível a aprovação de uma Emenda Constitucional para retirar-lhes a vigência, em virtude da proteção conferida pela Lei Maior às cláusulas pétreas (art. $60, \S 4^{\circ}$, inciso IV), não sendo possível emendar a Constituição para suprimir direitos fundamentais anteriormente incorporados.

${ }^{46}$ REZEK, José Francisco. Direito internacional público: curso elementar. 11. ed. São Paulo: Saraiva, 2008. p. 107-108.

${ }^{47}$ Em sentido contrário, entendendo que os tratados sobre direitos humanos material e formalmente constitucionais (ou seja, incorporados na forma do art. $5^{\circ}, \S 3^{\circ}$, da Constituição Federal) são insuscetíveis de denúncia: PIOVESAN, Flávia. Direitos humanos e o direito constitucional internacional. 10. ed. São Paulo: Saraiva, 2009. p. 80-81. 


\section{A mudança de entendimento do Supremo Tribunal Federal ocorrida em dezembro de 2008}

No dia 3 de dezembro de 2008, o plenário do Supremo Tribunal Federal finalizou o julgamento de diversos casos relacionados à prisão civil do depositário infiel. Nesses julgamentos (Habeas Corpus de no 87.585/TO e 92.566/SP e Recursos Extraordinários de no $349.703 / \mathrm{RS}$ e 466.343/SP), formaram-se duas correntes antagônicas a respeito da hierarquia dos tratados internacionais sobre direitos humanos incorporados anteriormente à Emenda Constitucional no 45/2004: a primeira, capitaneada pelo Ministro Gilmar Mendes e que se tornou vencedora, defendendo o status supralegal desses tratados; a segunda, liderada pelo Ministro Celso de Mello, sustentando que esses tratados possuem status constitucional. ${ }^{48}$

\subsection{As novas posições dos Ministros do Supremo Tribunal Federal}

Como vimos no capítulo 2, desde 1977, quando do julgamento do Recurso Extraordinário no 80.004/SE, o Supremo Tribunal Federal vem entendendo que os tratados internacionais incorporados no direito interno têm o mesmo status da

\footnotetext{
${ }^{48}$ Esclareça-se que a divergência aqui abordada não é quanto ao resultado do julgamento de cada um desses acórdãos (dois deles, o Habeas Corpus n 87.585/TO e o Recurso Extraordinário $\mathrm{n}^{\circ} 466.343 / \mathrm{SP}$, inclusive são unânimes), mas sim quanto à fundamentação utilizada nos votos individuais acerca do status dos tratados internacionais sobre direitos humanos incorporados antes da Emenda Constitucional no 45/2004. Segundo a contagem do Ministro Celso de Mello, na atual composição do Supremo Tribunal Federal, os Ministros Gilmar Mendes, Carlos Britto, Menezes Direito, Ricardo Lewandowsky e Cármen Lúcia consideram que esses tratados possuem status supralegal, enquanto os Ministros Celso de Mello, Cezar Peluso, Eros Grau e Ellen Gracie atribuem status constitucional a esses tratados, sendo que os Ministros Marco Aurélio e Joaquim Barbosa não se manifestaram sobre a questão durante o julgamento. BRASIL. Supremo Tribunal Federal. Habeas Corpus $n^{\circ}$ 92.566/SP. Ementário de Jurisprudência do Supremo Tribunal Federal, v. 2.363, t. 3, p. 466-467, 5 jun. 2009. Note-se que o Ministro Cezar Peluso, embora tenha afirmado, durante o julgamento, que ainda não havia se definido entre o status supralegal ou constitucional desses tratados, e que essa definição era irrelevante para o deslinde da questão. BRASIL. Supremo Tribunal Federal. Recurso Extraordinário n $466.343 /$ SP. Ementário de Jurisprudência do Supremo Tribunal Federal, v. 2.363, t. 6, p. 1.271-1.272, 1.277 e 1.282, 5 jun. 2009), em sua última manifestação assumiu a posição que defende a hierarquia constitucional. BRASIL. Supremo Tribunal Federal. Recurso Extraordinário no 466.343/ SP. Ementário de Jurisprudência do Supremo Tribunal Federal, v. 2.363, t. 6, p. 1.305-1.306, 5 jun. 2009).
} 
legislação infraconstitucional. Esse entendimento foi mantido após a promulgação da Constituição Federal de 1988, mesmo para os tratados internacionais sobre direitos humanos. ${ }^{49}$

Trinta e dois anos depois, eis que nossa Corte Maior, numa mudança absolutamente radical de entendimento, abandona a posição anterior e passa a se dividir entre duas novas possibilidades: conferir status supralegal ou status constitucional a esses mesmos instrumentos jurídicos. E note-se: nem mesmo a Emenda Constitucional no 45/2004 é motivo para tão revolucionária mudança, na medida em que o debate nesses julgados limitou-se aos tratados internalizados no Brasil antes de sua vigência (os casos julgados em 3 de dezembro de 2008 tratam, todos eles, da Convenção Americana sobre Direitos Humanos e sua relação com a prisão civil do depositário infiel).

Segundo o Ministro Gilmar Mendes, é possível o controle prévio de constitucionalidade dos tratados, pois o Decreto Legislativo que os aprova está sujeito ao controle de constitucionalidade..$^{50} \mathrm{O}$ art. $5^{\circ}, \S 3^{\circ}$, da Constituição Federal, teria esvaziado a tese da hierarquia constitucional dos tratados de direitos humanos anteriormente incorporados no nosso ordenamento jurídico, ao exigir procedimento legislativo especial para alcance desse status hierárquico. Todavia, essa mudança teria ressaltado o caráter especial dos tratados de direitos humanos em relação

${ }^{49}$ A respeito do tema, os mais importantes julgamentos do plenário do Supremo Tribunal Federal na vigência da Constituição de 1988 foram: BRASIL. Supremo Tribunal Federal. Habeas Corpus no 72.131/RJ. Ementário de Jurisprudência do Supremo Tribunal Federal, v. 2.117 , t. 40 , p. $8.650-8.750,1^{\circ}$ ago. 2003; BRASIL. Supremo Tribunal Federal. Medida Cautelar na Ação Direta de Inconstitucionalidade no 1.480 /DF. Ementário de Jurisprudência do Supremo Tribunal Federal, v. 2.031, t. 2, p. 213-365, 18 mai. 2001; BRASIL. Supremo Tribunal Federal. Habeas Corpus n ${ }^{\circ} 76.561 /$ SP. Ementário de Jurisprudência do Supremo Tribunal Federal, v. 2.017, t. 2, p. 294-327, 2 fev. 2001; BRASIL. Supremo Tribunal Federal. Recurso Extraordinário no 206.482/SP. Ementário de Jurisprudência do Supremo Tribunal Federal, v. 2.122, t. 4, p. 661-733, 5 set. 2003; BRASIL. Supremo Tribunal Federal. Recurso Ordinário em Habeas Corpus no 79.785/RJ. Ementário de Jurisprudência do Supremo Tribunal Federal, v. 2.092, t. 2, p. 280-324, 22 nov. 2002; e BRASIL. Supremo Tribunal Federal. Habeas Corpus no 81.319/GO. Ementário de Jurisprudência do Supremo Tribunal Federal, v. 2.201, t. 2, p. 186-245, 19 ago. 2005.

${ }^{50}$ Conforme os seguintes votos por ele proferidos: BRASIL. Supremo Tribunal Federal. Recurso Extraordinário no 349.703/RS. Ementário de Jurisprudência do Supremo Tribunal Federal, v. 2.363, t. 4, p. 714, 5 jun. 2009; e BRASIL. Supremo Tribunal Federal. Recurso Extraordinário no 466.343/SP. Ementário de Jurisprudência do Supremo Tribunal Federal, v. 2.363 , t. 6 , p. $1.141,5$ jun. 2009. 
aos demais tratados, conferindo-lhes lugar privilegiado no ordenamento jurídico, abaixo da Constituição, mas acima da legislação infraconstitucional. Ou seja, o Ministro Gilmar Mendes adotou a tese da supralegalidade. ${ }^{51}$ Ele conclui afirmando que nada impede que o legislador constitucional submeta os tratados de direitos humanos já incorporados ao procedimento especial do art. $5^{\circ}, \S 3^{\circ}$, da Constituição Federal. ${ }^{52}$

Já para o Ministro Celso de Mello, antes mesmo da Emenda Constitucional $n^{\circ} 45 / 2004$, que acrescentou ao art. $5^{\circ}$ da Constituição Federal o atual $\$ 3^{\circ}$, o art. 5, $\$ 2^{\circ}$, da nossa Lei Maior, já autorizava

[...] o reconhecimento de que os tratados internacionais de direitos humanos possuem hierarquia constitucional, em face da relevantíssima circunstância de que viabilizam a incorporação, ao catálogo constitucional de direitos e garantias individuais, de outras prerrogativas e liberdades fundamentais, que passam a integrar, subsumindo-se ao seu conceito, o conjunto normativo configurador do bloco de constitucionalidade. ${ }^{53}$

Como essa divergência foi decidida por apertada maioria (cinco votos a favor da tese da hierarquia supralegal contra quatro votos a favor da tese da hierarquia constitucional), e como os Ministros Marco Aurélio e Joaquim Barbosa preferiram não assumir uma posição definida a respeito do tema nos julgamentos

${ }^{51}$ Conforme os seguintes votos por ele proferidos: BRASIL. Supremo Tribunal Federal. Recurso Extraordinário no 349.703/RS. Ementário de Jurisprudência do Supremo Tribunal Federal, v. 2.363, t. 4, p. 717-720, 725-728, 733-734 e 764, 5 jun. 2009; e BRASIL. Supremo Tribunal Federal. Recurso Extraordinário n 466.343/SP. Ementário de Jurisprudência do Supremo Tribunal Federal, v. 2.363, t. 6, p. 1.144-1.147, 1.152-1.155, 1.160-1.161 e 1.191, 5 jun. 2009.

${ }^{52}$ Conforme os seguintes votos por ele proferidos: BRASIL. Supremo Tribunal Federal. Recurso Extraordinário no 349.703/RS. Ementário de Jurisprudência do Supremo Tribunal Federal, v. 2.363, t. 4, p. 734, 5 jun. 2009; e BRASIL. Supremo Tribunal Federal. Recurso Extraordinário no 466.343/SP. Ementário de Jurisprudência do Supremo Tribunal Federal, v. 2.363 , t. 6 , p. $1.161,5$ jun. 2009.

${ }^{53}$ Conforme os seguintes votos por ele proferidos: BRASIL. Supremo Tribunal Federal. Habeas Corpus no 87.585/TO. Ementário de Jurisprudência do Supremo Tribunal Federal, v. 2.366, t. 2, p. 286, 26 jun. 2009; BRASIL. Supremo Tribunal Federal. Recurso Extraordinário no 349.703/RS. Ementário de Jurisprudência do Supremo Tribunal Federal, v. 2.363, t. 4, p. 805, 5 jun. 2009; e BRASIL. Supremo Tribunal Federal. Recurso Extraordinário $n^{\circ} 466.343 /$ SP. Ementário de Jurisprudência do Supremo Tribunal Federal, v. 2.363, t. 6, p. 1.247, 5 jun. 2009. 
ocorridos em 3 de dezembro de 2008, não se pode descartar a hipótese de que haja, brevemente, nova mudança na jurisprudência do Supremo Tribunal Federal a respeito do tema, dessa vez a favor da tese da hierarquia constitucional dos tratados internacionais sobre direitos humanos internalizados antes da Emenda Constitucional no $45 / 2004 .^{54}$

Importante ressaltar a radical mudança de entendimento do Ministro Celso de Mello, que nos julgamentos anteriores defendeu veementemente a po-

54 Tudo vai depender de como vão se posicionar, a partir de agora, os Ministros Marco Aurélio e Joaquim Barbosa. A possibilidade existe porque este último, em julgado da Segunda Turma do Supremo Tribunal Federal posterior aos acórdãos ora analisados, passou a sustentar o status constitucional dos tratados internacionais de direitos humanos internalizados antes da Emenda Constitucional no 45/2004. No caso, o Ministro, referindo-se à Convenção Americana sobre Direitos Humanos (Pacto de São José da Costa Rica), afirmou: "Com efeito, após o advento da Emenda Constitucional 45/04, consoante redação dada ao $\$ 3^{\circ}$ do artigo $5^{\circ}$ da Constituição Federal, passou-se a atribuir às convenções internacionais sobre direitos humanos hierarquia constitucional... Desse modo, a Corte deve evoluir do entendimento então prevalecente à época do julgado aludido, para reconhecer a hierarquia constitucional da Convenção" BRASIL. Supremo Tribunal Federal. Agravo Regimental no Agravo de Instrumento ${ }^{\circ}$ 601.832/SP. Ementário de Jurisprudência do Supremo Tribunal Federal, v. 2.355, t. 6, p. 1.140, 3 abr. 2009. Dessa forma, muito provavelmente, se a questão for novamente levada ao plenário, teremos cinco votos defendendo essa posição (Ministros Celso de Mello, Cezar Peluso, Eros Grau, Ellen Gracie e Joaquim Barbosa) e cinco votos sustentando a tese do status supralegal dos tratados incorporados antes da Emenda Constitucional no 45/2004 (Ministros Gilmar Mendes, Carlos Britto, Menezes Direito, Ricardo Lewandowsky e Cármen Lúcia). Já o Ministro Marco Aurélio, nas oportunidades em que se manifestou expressamente sobre o tema, sempre considerou que os tratados em questão possuem hierarquia infraconstitucional: "O preceito da Convenção Americana sobre Direitos Humanos, limitador de prisão por dívida passou a viger com estatura de legislação ordinária...”. BRASIL. Supremo Tribunal Federal. Habeas Corpus $n^{\circ} 72.131 / R J$. Ementário de Jurisprudência do Supremo Tribunal Federal, v. 2.117, t. 40 , p. 8.664, 1 ago. 2003. Todavia, frente às novas linhas de raciocínio manifestadas pela atual composição da corte, e diante do empate iminente entre elas numa eventual votação do plenário, o Ministro Marco Aurélio poderá realinhar a sua posição para aderir a uma das duas correntes atualmente majoritárias.

${ }^{55}$ Do voto proferido pelo Ministro Celso de Mello no julgamento, pelo Supremo Tribunal Federal, do Habeas Corpus no 72.131/RJ, constam as seguintes passagens: "Na realidade, inexiste, na perspectiva do modelo constitucional vigente no Brasil, qualquer precedência ou primazia hierárquico-normativa dos tratados ou convenções internacionais sobre o direito positivo interno, sobretudo em face das cláusulas inscritas no texto da Constituição da República, eis que a ordem normativa externa não se superpõe, em hipótese alguma, ao que prescreve a Lei Fundamental da República". BRASIL. Supremo Tribunal Federal. Habeas Corpus nº 72.131/RJ. Ementário de Jurisprudência do Supremo Tribunal Federal, v. 2.117, t. 40, p. 8.726, 1 ago. 2003; 
sição da hierarquia infraconstitucional dos tratados internacionais sobre direitos humanos, ${ }^{55}$ e agora está liderando, dentro do Tribunal, a corrente que prega o status constitucional desses mesmos instrumentos jurídicos. ${ }^{56}$

A respeito da mudança de entendimento do tribunal de cúpula do país, vale transcrever a perspicaz observação de Amaral Júnior:

\footnotetext{
"Os tratados internacionais não podem transgredir a normatividade emergente da Constituição, pois, além de não disporem de autoridade para restringir a eficácia jurídica das cláusulas constitucionais, não possuem força para conter ou para delimitar a esfera de abrangência normativa dos preceitos inscritos no texto da Lei Fundamental”. BRASIL. Supremo Tribunal Federal. Habeas Corpus no 72.131/RJ. Ementário de Jurisprudência do Supremo Tribunal Federal, v. 2.117, t. 40, p. 8.728, 1 ago. 2003; "Parece-se irrecusável, no exame da questão concernente à primazia das normas de direito internacional público sobre a legislação interna ou doméstica do Estado brasileiro, que não cabe atribuir, por efeito do que prescreve o art. $5^{\circ}, \$ 2^{\circ}$, da Carta Política, um inexistente grau hierárquico das convenções internacionais sobre o direito positivo interno vigente no Brasil, especialmente sobre as prescrições fundadas em texto constitucional, sob pena de essa interpretação inviabilizar, com manifesta ofensa à supremacia da Constituição - que expressamente autoriza a instituição da prisão civil do depositário infiel (CF, art. $5^{\circ}$, LXVII) -, o próprio exercício, pelo Congresso Nacional, de sua típica atividade político-jurídica consistente no desempenho da função de legislar". BRASIL. Supremo Tribunal Federal. Habeas Corpus $n^{\circ} 72.131 / R J$. Ementário de Jurisprudência do Supremo Tribunal Federal, v. 2.117, t. 40, p. 8.729, 1 ago. 2003; "A indiscutível supremacia da ordem constitucional brasileira sobre os tratados internacionais, além de traduzir um imperativo que decorre de nossa própria Constituição (art. 102, III, b), reflete o sistema, que, com algumas poucas exceções, tem prevalecido no plano do direito comparado, que considera inválida a convenção internacional que se oponha, que restrinja o conteúdo eficacial ou que importe em alteração da Lei Fundamental..." BRASIL. Supremo Tribunal Federal. Habeas Corpus n 72.131/RJ. Ementário de Jurisprudência do Supremo Tribunal Federal, v. 2.117, t. 40, p. 8.731, 1 ago. 2003. No mesmo sentido, os votos proferidos pelo Ministro Celso de Mello nos seguintes julgados: BRASIL. Supremo Tribunal Federal. Medida Cautelar na Ação Direta de Inconstitucionalidade $n^{\circ}$ 1.480/DF. Ementário de Jurisprudência do Supremo Tribunal Federal, v. 2.031 , t. 2, p. 232-240 e 281-283, 18 mai. 2001; e BRASIL. Supremo Tribunal Federal. Recurso Extraordinário no 206.482/SP. Ementário de Jurisprudência do Supremo Tribunal Federal, v. 2.122, t. 4, p. 722-727, 5 set. 2003.

${ }^{56}$ A justificativa do Ministro Celso de Mello para a sua mudança de entendimento consta dos seguintes acórdãos: BRASIL. Supremo Tribunal Federal. Habeas Corpus n 87.585/ TO. Ementário de Jurisprudência do Supremo Tribunal Federal, v. 2.366, t. 2, p. 268-289, 26 jun. 2009; BRASIL. Supremo Tribunal Federal. Recurso Extraordinário no 349.703/ RS. Ementário de Jurisprudência do Supremo Tribunal Federal, v. 2.363, t. 4, p. 787-808, 5 jun. 2009; e BRASIL. Supremo Tribunal Federal. Recurso Extraordinário no 466.343/SP. Ementário de Jurisprudência do Supremo Tribunal Federal, v. 2.363, t. 6, p. 1.229-1250, 5 jun. 2009.
} 
A verdadeira novidade, não em processo constitucional, mas com evidente influxo sobre o processo constitucional brasileiro, novidade essa com potencial revolucionário, é a nova composição do STF.

Nos últimos sete anos, oito Ministros do STF aposentaramse, dois deles no segundo governo Fernando Henrique Cardoso e $\operatorname{seis}^{57}$ - maioria absoluta - no governo Luís Inácio Lula da Silva.

Com isso, diversos entendimentos jurisprudenciais, que eram pacíficos há anos no STF, entraram em rediscussão. Alguns deles já foram modificados. Os efeitos deste fato podem ser bons ou maus conforme a percepção do jurisdicionado afetado. Ainda assim, de modo objetivo, é fácil perceber que não há nisso benefício à segurança jurídica. ${ }^{58}$

\subsection{Análise crítica do debate ocorrido no julgamento, pelo Supremo Tribunal Federal, dos Habeas Corpus de no 87.585/TO e 92.566/SP e dos Recursos Extraordinários de n 349.703/RS e 466.343/SP}

A tese da hierarquia constitucional, defendida pelo Ministro Celso de Mello, pode ser criticada porque admite que um tratado sobre direitos humanos aprovado com o procedimento e o quórum exigidos para as leis ordinárias tenha status de emenda constitucional. Segundo a Constituição Federal, frise-se, apenas

${ }^{57}$ Com a aposentadoria do Ministro Sepúlveda Pertence, agora são sete. Da atual composição do Supremo Tribunal Federal, o Ministro Celso de Mello foi indicado no governo do Presidente José Sarney; o Ministro Marco Aurélio foi indicado no governo do Presidente Fernando Collor; os Ministros Ellen Gracie e Gilmar Mendes foram indicados no governo do Presidente Fernando Henrique Cardoso; e os Ministros Cezar Peluso, Carlos Britto, Joaquim Barbosa, Eros Grau, Ricardo Lewandowsky, Cármen Lúcia e Menezes Direito foram indicados no governo do Presidente Luiz Inácio Lula da Silva (conforme tabela disponível em: < http://www. stf.jus.br/arquivo/cms/sobreStfComposicaoMinistroApresentacao/anexo/linha_sucessoria_ ministros_tabela.pdf>. Acesso em: 16 ago. 2009).

${ }^{58}$ AMARAL JÚNIOR, José Levi Mello do. Processo constitucional no Brasil: nova composição do STF e mutação constitucional. Revista de Direito Constitucional e Internacional, São Paulo, v. 14, n. 57, p. 103, out./dez., 2006. O autor ainda conclui o seu trabalho afirmando que "um mesmo texto legal não pode e não deve ser interpretado pelo Poder Judiciário de diferentes maneiras, mormente pelo seu órgão de cúpula. O STF deve contrabalançar os abusos da maioria, não lhes tomar o lugar” AMARAL JÚNIOR, José Levi Mello do. Processo constitucional no Brasil: nova composição do STF e mutação constitucional. Revista de Direito Constitucional e Internacional, São Paulo, v. 14, n. 57, p. 107-108, out./dez., 2006. 
os diplomas internacionais sobre direitos humanos, desde que aprovados na forma do art. $5^{\circ}, \S 3^{\circ}$, podem alcançar esse grau especial.

Ademais, se a redação do art. $5^{\circ}, \$ 2^{\circ}$, da Lei Maior, fosse realmente suficiente para atribuir status constitucional aos tratados sobre direitos humanos, por que razão o legislador constituinte derivado reformador teria se preocupado em acrescentar ao mesmo dispositivo o atual $\$ 3^{\circ}$, que estaria, portanto, sem qualquer função? ${ }^{59}$ Não parece aceitável, nem coerente, que o legislador teria o trabalho de emendar a Constituição, acrescentando um novo dispositivo (agora exigindo garantias maiores quanto ao procedimento e ao quórum), apenas para reforçar o efeito jurídico anteriormente reconhecido noutro dispositivo constitucional. Nisso reside a fragilidade da tese.

Também não vale invocar o direito comparado para sustentar essa interpretação: é na Constituição Federal, e não no direito comparado, que se deve buscar a fundamentação jurídica para encontrar o grau de hierarquia, no sistema jurídico, tanto dos tratados sobre direitos humanos quanto de quaisquer outras normas jurídicas.

O Ministro Gilmar Mendes faz uma crítica inteligente aos defensores do status constitucional automático dos tratados sobre direitos humanos incorporados anteriormente à Emenda Constitucional no 45/2004. ${ }^{60}$ Todavia, a sua posição também pode ser criticada por fundamentar o status supralegal desses instrumentos jurídicos no "Estado Constitucional Cooperativo" de Häberle ${ }^{61}$ (obrigação dos Estados em contribuir para a máxima eficácia das constituições modernas, que pro-

\footnotetext{
${ }^{59} \mathrm{Ou}$, no dizer de Piovesan, com a singela função de "reforçar" a natureza constitucional que esses tratados já possuíam: "Reitere-se que, por força do art. $5^{\circ}, \S 2^{\circ}$, todos os tratados de direitos humanos, independentemente do quorum de sua aprovação, são materialmente constitucionais, compondo o bloco de constitucionalidade. O quorum qualificado (do art. $5^{\circ}, \$ 3^{\circ}, \mathrm{CF}$ ) está tão-somente a reforçar tal natureza, ao adicionar um lastro formalmente constitucional aos tratados ratificados, propiciando a 'constitucionalização formal' dos tratados de direitos humanos no âmbito jurídico interno" PIOVESAN, Flávia. Direitos humanos e o direito constitucional internacional. 10. ed. São Paulo: Saraiva, 2009. p. 72.

${ }^{60}$ Conforme os seguintes votos por ele proferidos: BRASIL. Supremo Tribunal Federal. Recurso Extraordinário no 349.703/RS. Ementário de Jurisprudência do Supremo Tribunal Federal, v. 2.363, t. 4, p. 717, 5 jun. 2009; e BRASIL. Supremo Tribunal Federal. Recurso Extraordinário no 466.343/SP. Ementário de Jurisprudência do Supremo Tribunal Federal, v. 2.363 , t. 6 , p. $1.144,5$ jun. 2009.

${ }^{61}$ HÄBERLE, Peter. Estado constitucional cooperativo. Rio de Janeiro: Renovar, 2007.
} 
tegem a cooperação internacional amistosa e a proteção dos direitos humanos $)^{62} \mathrm{e}$ no direito comparado. ${ }^{63}$

O primeiro argumento seria mais facilmente utilizável pelos defensores da tese do status constitucional automático. A tese também não possui qualquer embasamento na Constituição brasileira, embasamento normativo esse existente em todos os exemplos de direito comparado que o Ministro utilizou. ${ }^{64}$ Não se pode falar, no Brasil, de supralegalidade, pois cabe à Constituição estabelecer a hierarquia das normas ${ }^{65} \mathrm{e}$ ela não prevê status supralegal para qualquer espécie normativa. Repita-se: é na Constituição Federal, e não no direito comparado, que se deve buscar a fundamentação jurídica para encontrar o grau de hierarquia, no sistema jurídico, tanto dos tratados sobre direitos humanos quanto de quaisquer outras normas jurídicas.

Além disso, o Ministro Gilmar Mendes limita-se a taxar de anacrônico o antigo entendimento do Supremo Tribunal Federal (de atribuir status infraconstitucional aos tratados sobre direitos humanos), com base na doutrina de Cança-

${ }^{62}$ Conforme os seguintes votos por ele proferidos: BRASIL. Supremo Tribunal Federal. Recurso Extraordinário no 349.703/RS. Ementário de Jurisprudência do Supremo Tribunal Federal, v. 2.363, t. 4, p. 721-722, 5 jun. 2009; e BRASIL. Supremo Tribunal Federal. Recurso Extraordinário no 466.343/SP. Ementário de Jurisprudência do Supremo Tribunal Federal, v. 2.363, t. 6, p. 1.148-1.149, 5 jun. 2009.

${ }^{63}$ Conforme os seguintes votos por ele proferidos: BRASIL. Supremo Tribunal Federal. Recurso Extraordinário no 349.703/RS. Ementário de Jurisprudência do Supremo Tribunal Federal, v. 2.363, t. 4, p. 722-725, 5 jun. 2009; e BRASIL. Supremo Tribunal Federal. Recurso Extraordinário no 466.343/SP. Ementário de Jurisprudência do Supremo Tribunal Federal, v. 2.363, t. 6, p. 1.149-1.152, 5 jun. 2009.

${ }^{64} \mathrm{O}$ Ministro Gilmar Mendes referiu-se às Constituições italiana, portuguesa, espanhola, paraguaia e argentina, transcrevendo, de todas elas, dispositivos que claramente atribuem aos tratados internacionais sobre direitos humanos status constitucional ou supralegal. Vide os seguintes votos por ele proferidos: BRASIL. Supremo Tribunal Federal. Recurso Extraordinário no 349.703/RS. Ementário de Jurisprudência do Supremo Tribunal Federal, v. 2.363 , t. 4 , p. $722-725,5$ jun. 2009; e BRASIL. Supremo Tribunal Federal. Recurso Extraordinário no 466.343/SP. Ementário de Jurisprudência do Supremo Tribunal Federal, v. 2.363 , t. 6, p. 1.149-1.152, 5 jun. 2009.

${ }^{65}$ A respeito, vide os arts. 59 a 69 da Constituição Federal.

${ }^{65}$ Conforme os seguintes votos por ele proferidos: BRASIL. Supremo Tribunal Federal. Recurso Extraordinário no 349.703/RS. Ementário de Jurisprudência do Supremo Tribunal Federal, v. 2.363, t. 4, p. 725-726 e 733, 5 jun. 2009; e BRASIL. Supremo Tribunal Federal. 
do Trindade, ${ }^{66}$ que, estranhamente, é um defensor não da supralegalidade, mas da constitucionalidade desses diplomas jurídicos. ${ }^{67}$

\section{Conclusão}

O Pacto Internacional de Direitos Econômicos, Sociais e Culturais, o Pacto Internacional de Direitos Civis e Políticos e a Convenção Americana sobre Direitos Humanos (Pacto de São José da Costa Rica), da mesma forma que todos os tratados sobre direitos humanos incorporados antes da Emenda Constitucional $n^{\circ}$ 45/2004 (inclusive os tratados internalizados na vigência das constituições anteriores, e que tenham sido recepcionados pela Constituição de 1988), por terem sido aprovados pelo Congresso Nacional com o quórum de maioria simples e mediante o mesmo procedimento exigido para as leis ordinárias, possuem, indubitavelmente, hierarquia infraconstitucional. Essa é a mais coerente das quatro posições existentes na doutrina nacional. ${ }^{68}$

Como a Constituição Federal não estabelece o status jurídico dos tratados internacionais (exceto na hipótese do art. $5^{\circ}, \S 3^{\circ}$, que se refere aos tratados internacionais sobre direitos humanos incorporados após a Emenda Constitucional $n^{\circ} 45 / 2004$, exigindo procedimento especial e quórum qualificado para aprovação daqueles diplomas com status de emenda constitucional), ${ }^{69}$ não parece possível atribuir àqueles instrumentos outra hierarquia que não seja a infraconstitucional, sob pena de o intérprete criar norma de status jurídico não previsto na Lei Maior (caso seja atribuído status supralegal) ou de conferir nível constitucional a uma norma contrariando a própria Constituição, que não o fez expressamente (caso seja reconhecido status constitucional).

Nada impede, todavia, que esses tratados, que versam sobre direitos humanos, sejam novamente submetidos ao Congresso Nacional, na forma do art. $5^{\circ}, \S 3^{\circ}$, da Constituição Federal, com a finalidade de que venham a alcançar

Recurso Extraordinário no 466.343/SP. Ementário de Jurisprudência do Supremo Tribunal Federal, v. 2.363, t. 6, p. 1.152-1.153 e 1.160, 5 jun. 2009.

${ }^{67}$ CANÇADO TRINDADE, Antônio Augusto. Tratado de direito internacional dos direitos humanos. 2. ed. Porto Alegre: S. A. Fabris, 2003. v. 1, p. 513.

${ }^{68}$ Essas posições foram examinadas no capítulo 2.

${ }^{69}$ A hipótese foi tratada nos capítulos 3 e 4. 
status de norma constitucional. ${ }^{70} \mathrm{E}$, caso não alcancem o quórum necessário (três quintos dos votos dos membros de cada uma das casas do Congresso Nacional, em dois turnos), continuarão, evidentemente, possuindo nível hierárquico infraconstitucional.

Já os instrumentos jurídicos internacionais aprovados pelo Congresso Nacional na forma do art. $5^{\circ}, \$ 3^{\circ}$, da Constituição Federal, possuem inegavelmente hierarquia constitucional. Trata-se do único caso em que o grau hierárquico dos tratados internacionais dentro do sistema jurídico é atribuído expressamente pela Lei Maior.

Por outro lado, o art. $5^{\circ}, \S 3^{\circ}$, da Constituição Federal, não veda a internalização desses instrumentos jurídicos por meio da forma antiga, sem as novas exigências, mas com status infraconstitucional, de forma que o tratado sobre direitos humanos que não atingir a maioria qualificada exigida no novo dispositivo, mas que obtiver a maioria simples dos votos pela sua aprovação no primeiro turno de votação, em cada casa do Congresso Nacional, não estará rejeitado, mas sim aprovado, embora sem status de emenda constitucional. ${ }^{71}$

Diante dessa situação, coexistem dois níveis hierárquicos distintos para os tratados internacionais sobre direitos humanos no Brasil: 1) os instrumentos que foram incorporados antes da Emenda Constitucional no 45/2004 (aí incluídos aqueles internalizados antes da promulgação da Constituição de 1988, mas por ela recepcionados) ou que, incorporados após a referida Emenda, não tenham alcançado o quórum qualificado de três quintos dos votos dos membros de ambas as casas do Congresso Nacional, em dois turnos, mas que tenham alcançado pelo menos a maioria simples dos votos no primeiro turno de votação, tanto na Câmara dos Deputados quanto no Senado Federal (com status infraconstitucional em ambos os casos); e 2) os diplomas que foram incorporados posteriormente àquela Emenda Constitucional, e que foram aprovados na forma e com o quórum previstos no art. $5^{\circ}, \S 3^{\circ}$, da Constituição Federal (com status constitucional).

A existência de normas da mesma origem (tratados internacionais sobre direitos humanos), mas que possuem hierarquia diversa dentro do sistema jurídi-

\footnotetext{
${ }^{70}$ Vide o item 4.2.

${ }^{71}$ Vide o item 4.3 .
} 
co, ao contrário do que pode parecer num primeiro momento, não é uma situação estranha ou incoerente. Assim como no direito internacional têm origem diplomas sobre o mesmo tema, mas que são incorporados no ordenamento jurídico nacional com hierarquias distintas, também a ordem interna pode dar origem a normas jurídicas que tratam do mesmo assunto, mas que estão incluídas em espécies normativas diversas (entre aquelas constantes do art. 59 da Constituição Federal), e até mesmo com status jurídicos diferentes.

Alguns diriam que um tratado sobre direitos humanos (como o Pacto de São José da Costa Rica) tem uma importância muito maior do que um simples acordo cultural (como o recente Acordo Ortográfico da Língua Portuguesa). ${ }^{72}$ É verdade. Mas uma lei ordinária como o Código de Defesa do Consumidor também é muito mais importante do que outra lei ordinária que dá nome a uma rodovia. $\mathrm{E}$ nem por isso elas possuem status jurídicos diferentes. São normas aprovadas pelo Congresso Nacional por meio do mesmo procedimento, e com o mesmo quórum de aprovação, e por isso devem possuir o mesmo status hierárquico dentro do sistema jurídico. Isso também acontece com os tratados internacionais.

É, portanto, a forma de aprovação pelo legislativo (aí incluídos o procedimento e o quórum), e não a opinião pessoal do intérprete, que define o status hierárquico de cada norma dentro do sistema jurídico. Basta aplicar o mesmo raciocínio aos tratados internacionais.

Justamente por isso, deve competir sempre ao Congresso Nacional decidir sobre a forma de incorporação dos tratados internacionais (e, portanto, sobre o respectivo status no sistema normativo). Por isso, não parece recomendável diferenciar, na Constituição, quanto ao status normativo, os tratados em geral dos tratados sobre direitos humanos. Aí está a inteligência do art. $5^{\circ}, \S 2^{\circ}$, da Lei Maior, que infelizmente não foi repetida no art. $5^{\circ}, \S 3^{\circ}$.

O efeito da reforma, na verdade, foi apenas o de vedar a possibilidade da existência de tratados que não versam sobre direitos humanos com hierarquia constitucional. ${ }^{73}$

\footnotetext{
${ }^{72}$ Aprovado pelo Decreto Legislativo $\mathrm{n}^{\circ}$ 54, de 18 de abril de 1995, e promulgado pelo Decreto $\mathrm{n}^{\circ} 6.583$, de 29 de setembro de 2008 .

${ }^{73}$ Vide o item 4.1 .
} 


\title{
The hierarchy of international treaties on human rights in Brazil
}

\begin{abstract}
This paper seeks to identify the hierarchy of international treaties on human rights in Brazilian law. Initially, analyzes the human rights treaties incorporated before the advent of Constitutional Amendment $n^{\circ} 45 / 2004$ and the doctrinal positions on the theme existing until then. Then, studies the contents of the Constitutional Amendment $n^{\circ} 45 / 2004$, the their implications on the hierarchy of the human rights treaties incorporated both before when after its enactment and interpretative problems arising of the new constitutional text. Lastly, verifies the jurisprudence modification of the Brazilian Federal Supreme Court in respect of the matter occurred in December 2008 to hold a critical analysis of new understandings of the Justices. Accepts the possibility of coexistence of two distinct hierarchical levels for the human rights treaties in Brazil and concludes that the form of approval of the treaty by the legislative determines their hierarchical status within the legal system.
\end{abstract}

Keywords: Treaties. Human rights. Hierarchy. Incorporation.

\section{Referências}

AMARAL JÚNIOR, José Levi Mello do. Reforma define status jurídico de tratados sobre direitos humanos. Disponível em: <http://www.conjur.com.br/2005-jan-26/ reforma_define_status_juridico_tratados_internacionais $>$. Acesso em: 15 ago. 2009.

AMARAL JÚNIOR, José Levi Mello do. Reforma sepulta chance de status constitucional automático a tratados. Disponível em: <http://www.conjur.com. br/2005-fev-01/reforma_nega_status_constitucional_automatico_tratados $>$. Acesso em: 15 ago. 2009.

AMARAL JÚNIOR, José Levi Mello do. Processo constitucional no Brasil: nova composição do STF e mutação constitucional. Revista de Direito Constitucional e Internacional, São Paulo, v. 14, n. 57, p. 100-108, out./dez. 2006.

BRASIL. Constituição (1988). Constituição da República Federativa do Brasil: promulgada em 5 de outubro de 1988. 42. ed. São Paulo: Saraiva, 2009. 
BRASIL Decreto no 591, de 6 jul. 1992. Atos internacionais. Pacto Internacional sobre Direitos Econômicos, Sociais e Culturais. Promulgação. Diário Oficial da União, Brasília, Seção 1, n. 128, 7 jul. 1992, p. 8.713-8.716.

BRASIL. Decreto no 592, de 6 jul. 1992. Atos internacionais. Pacto Internacional sobre Direitos Civis e Políticos. Promulgação. Diário Oficial da União, Brasília, Seção 1, n. 128, 7 jul. 1992, p. 8.716-8.720.

BRASIL. Decreto nº 678, de 6 nov. 1992. Promulga a Convenção Americana sobre Direitos Humanos (Pacto de São José da Costa Rica), de 22 de novembro de 1969. Diário Oficial da União, Brasília, Seção 1, n. 214, 9 nov. 1992, p. 15.562-15.567.

BRASIL. Decreto no 6.583, de 29 set. 2008. Promulga o Acordo Ortográfico da Língua Portuguesa, assinado em Lisboa, em 16 de dezembro de 1990. Diário Oficial da União, Brasília, Seção 1, n. 189, 30 set. 2008, p. 1-9.

BRASIL. Decreto Legislativo no 226, de 12 dez. 1991. Aprova os textos do Pacto Internacional sobre Direitos Civis e Políticos e do Pacto Internacional sobre Direitos Econômicos, Sociais e Culturais, ambos aprovados, junto com o Protocolo Facultativo relativo a esse último pacto, na XXI Seção (1966) da Assembléia-Geral das Nações Unidas. Diário Oficial da União, Brasília, Seção 1, n. 242, 13 dez. 1991, p. 28.838 .

BRASIL. Decreto Legislativo no 27, de 26 maio 1992. Aprova o texto da Convenção Americana sobre Direitos Humanos (Pacto São José) celebrado em São José da Costa Rica, em 22 de novembro de 1969, por ocasião da Conferência Especializada Interamericana sobre Direitos Humanos. Diário Oficial da União, Brasília, Seção 1, n. 101, 28 maio 1992, p. 6.586.

BRASIL. Decreto Legislativo no 54, de 18 abr. 1995. Aprova o texto do Acordo Ortográfico da Língua Portuguesa, assinado em Lisboa, em 16 de dezembro de 1990. Diário Oficial da União, Brasília, Seção 1, n. 76, 20 abr. 1995, p. 5.585.

BRASIL. Decreto Legislativo n 186, de 9 jul. 2008. Aprova o texto da Convenção sobre os Direitos das Pessoas com Deficiência e de seu Protocolo Facultativo, assinados em Nova Iorque, em 30 de mar. de 2007. Diário Oficial da União, Brasília, Seção 1, n. 131, 10 jul. 2008, p. 1.

BRASIL. Supremo Tribunal Federal. Tribunal Pleno. Recurso Extraordinário no 80.004/SE. Redator: Min. Cunha Peixoto. Acórdão de $1^{\circ}$ jun. 1977. Ementário de Jurisprudência do Supremo Tribunal Federal, Brasília, v. 1.083, t. 2, p. 915-1.024, 29 dez. 1977. 
BRASIL. Supremo Tribunal Federal. Tribunal Pleno. Habeas Corpus $n^{\circ} 72.131 / R J$. Redator: Min. Moreira Alves. Acórdão de 23 nov. 1995. Ementário de Jurisprudência do Supremo Tribunal Federal, Brasília, v. 2.117, t. 40, p. 8.650-8.750, 1º ago. 2003.

BRASIL. Supremo Tribunal Federal. Tribunal Pleno. Medida Cautelar na Ação Direta de Inconstitucionalidade $n^{\circ}$ 1.480/DF. Relator: Min. Celso de Mello. Acórdão de 4 nov. 1997. Ementário de Jurisprudência do Supremo Tribunal Federal, Brasília, v. 2.031, t. 2, p. 213-365, 18 maio 2001.

BRASIL. Supremo Tribunal Federal. Tribunal Pleno. Habeas Corpus $n^{\circ} 76.561 / S P$. Redator: Min. Nelson Jobim. Acórdão de 27 mai. 1998. Ementário de Jurisprudência do Supremo Tribunal Federal, Brasília, v. 2.017, t. 2, p. 294-327, 2 fev. 2001.

BRASIL. Supremo Tribunal Federal. Tribunal Pleno. Recurso Extraordinário $n^{\circ}$ 206.482/SP. Relator: Min. Maurício Corrêa. Acórdão de 27 mai. 1998. Ementário de Jurisprudência do Supremo Tribunal Federal, Brasília, v. 2.122, t. 4, p. 661-733, 5 set. 2003.

BRASIL. Supremo Tribunal Federal. Tribunal Pleno. Recurso Ordinário em Habeas Corpus $n^{\circ}$ 79.785/RJ. Relator: Min. Sepúlveda Pertence. Acórdão de 29 mar. 2000. Ementário de Jurisprudência do Supremo Tribunal Federal, Brasília, v. 2.092, t. 2, p. 280-324, 22 nov. 2002.

BRASIL. Supremo Tribunal Federal. Tribunal Pleno. Habeas Corpus no 81.319/GO. Relator: Min. Celso de Mello. Acórdão de 24 abr. 2002. Ementário de Jurisprudência do Supremo Tribunal Federal, Brasília, v. 2.201, t. 2, p. 186-245, 19 ago. 2005.

BRASIL. Supremo Tribunal Federal. Tribunal Pleno. Habeas Corpus $n^{\circ} 87.585 / T O$. Relator: Min. Marco Aurélio. Acórdão de 3 dez. 2008. Ementário de Jurisprudência do Supremo Tribunal Federal, Brasília, v. 2.366, t. 2, p. 237-365, 26 jun. 2009.

BRASIL. Supremo Tribunal Federal. Tribunal Pleno. Habeas Corpus no 92.566/SP. Relator: Min. Marco Aurélio. Acórdão de 3 dez. 2008. Ementário de Jurisprudência do Supremo Tribunal Federal, Brasília, v. 2.363, t. 3, p. 451-471, 5 jun. 2009.

BRASIL. Supremo Tribunal Federal. Tribunal Pleno. Recurso Extraordinário $n^{\circ}$ 349.703/RS. Relator: Min. Gilmar Mendes. Acórdão de 3 dez. 2008. Ementário de Jurisprudência do Supremo Tribunal Federal, Brasília, v. 2.363, t. 4, p. 675-876, 5 jun. 2009.

BRASIL. Supremo Tribunal Federal. Tribunal Pleno. Recurso Extraordinário $n^{\circ}$ 466.343/SP. Relator: Min. Cezar Peluso. Acórdão de 3 dez. 2008. Ementário de 
Jurisprudência do Supremo Tribunal Federal, Brasília, v. 2.363, t. 6, p. 1.106-1.330, 5 jun. 2009.

BRASIL. Supremo Tribunal Federal. Segunda Turma. Agravo Regimental no Agravo de Instrumento $n^{\circ}$ 601.832/SP. Relator: Min. Joaquim Barbosa. Acórdão de 17 mar. 2009. Ementário de Jurisprudência do Supremo Tribunal Federal, Brasília, v. 2.355, t. 6, p. 1.129-1.146, 3 abr. 2009.

CANÇADO TRINDADE, Antônio Augusto. Tratado de direito internacional dos direitos humanos. 2. ed. Porto Alegre: S. A. Fabris, 2003.

FERREIRA FILHO, Manoel Gonçalves. Direitos humanos fundamentais. 10. ed. São Paulo: Saraiva, 2008.

GALINDO, George Rodrigo Bandeira. Tratados internacionais de direitos humanos e Constituição brasileira. Belo Horizonte: Del Rey, 2002.

HÄBERLE, Peter. Estado constitucional cooperativo. Rio de Janeiro: Renovar, 2007.

MAZZUOLI, Valério de Oliveira. Curso de direito internacional público. 3. ed. São Paulo: RT, 2008.

MELLO, Celso de Albuquerque. $\mathrm{O} \$ 2^{\circ}$ do art. $5^{\circ}$ da Constituição Federal. In: TORRES, Ricardo Lobo (Org.). Teoria dos direitos fundamentais. 2. ed. Rio de Janeiro: Renovar, 2001.

MORAES, Alexandre de. Direito constitucional. 24. ed. São Paulo: Atlas, 2009.

PIOVESAN, Flávia. Direitos humanos e o direito constitucional internacional. 10. ed. São Paulo: Saraiva, 2009.

REZEK, José Francisco. Direito internacional público: curso elementar. 11. ed. São Paulo: Saraiva, 2008.

RODRIGUES, Maurício Andreiuolo. Os tratados internacionais de proteção dos direitos humanos e a constituição. In: TORRES, Ricardo Lobo (Org.). Teoria dos direitos fundamentais. 2. ed. Rio de Janeiro: Renovar, 2001.

SARLET, Ingo Wolfgang. A eficácia dos direitos fundamentais: uma teoria geral dos direitos fundamentais na perspectiva constitucional. 10. ed. Porto Alegre: Livraria do Advogado, 2009. 
SARLET, Ingo Wolfgang. A abertura material do catálogo constitucional dos direitos fundamentais e os tratados internacionais em matéria de direitos humanos: conteúdo e significado os parágrafos $2^{\circ}$ e $3^{\circ}$ do art. $5^{\circ}$ da Constituição Federal de 1988. In: ROCHA, Maria Elizabeth Guimarães Teixeira; MEYER-PFLUG, Samantha Ribeiro (Coord.). Lições de direito constitucional em homenagem ao professor Jorge Miranda. Rio de Janeiro: Forense, 2008. 
